10. Тихомиров Ю.А. Теория закона / отв. ред. В.П. Казимирчук. Москва : Изд-во «Наука», 1982. 255 с.

11. Фатхутдінова О. Теоретико-правові проблеми юридичного процесу : автореф. дис. ... канд. юрид. наук : 12.00.01. Київ, 2000. 28 с.

12. Федоренко В. Конституційне право України : підручник / До 20-ої річниці Конституції України та 25-ої річниці незалежності України. Київ : Видавництво Ліра-К, 2016. 616 с.

13. Цоклан В.І. Система сучасних джерел конституційного права України : монографія. Київ : Ліра-К, 2009. 400 с.

14. Ющенко О.О. Конституційно-правові засади участі громадян у законодавчому процесі України : дис. ... канд. юрид. наук : 12.00.02. Ужгород, 2016. 233 с.

15. Ющик O.I. Теоретичні основи законодавчого процесу : монографія. Київ : Парламентське вид-во, 2004. 519 с.

БЕРЧЕНКО Г. В., кандидат юридичних наук, доцент, доцент кафедри конституційного права України (Національний юридичний університет імені Ярослава Мудрого)

\title{
ПОПЕРЕДНІЙ КОНТРОЛЬ ЗА ЗМІНАМИ КОНСТИТУЦЇ̈: ЮРИДИЧНІ ПОЗИЦІї КОНСТИТУЦІЙНОГО СУДУ УКРАЇНИ
}

За 22 роки свого існування і КСУ надав висновки на 34 законопроекти щодо внесення змін до Конституції України. У висновках Конституційного Суду України часто йдеться про повноваження і статус органів державної влади й опосередковані обмеження прав людини. Причому Суд часто використовує конструкцію «можуть призвести до обмеження прав», «опосередковано може призвести до обмеження права», а не констатує факт скасування або обмеження прав пропонованими змінами. КСУ робить припущення про можливість обмеження, що юридично дорівнює самому обмеженню і робить висновок про порушення ч. 1 ст. 157. Іноді (за наявності схожої аргументації («може призвести до <...> обмеження конституційних прав громадян»)) КСУ просто констатує це як своє занепокоєння в мотивувальній частині рішення і робить протилежний висновок - зміни відповідають ст. 157 і 158. Все залежить від того, чи схиляються судді до судового активізму, чи до самообмеження, не кажучи про глибинні причини різного підходу до висновків. Проте найяскравіший приклад суддівського активізму - закриття провадження у разі «неузгодженості» змін, а також їх «блокування» через суперечність - іншим статтям Конституції України. Зауважимо, що починаючи з 2015 р. взагалі не надав жодного негативного (хоча б частково) висновку на законопроект про внесення змін до Конституції України, обмежуючись час від часу тим, що він сам називає «застереженнями». Відтоді загалом почався період «стриманості» в діяльності українського КСУ, принаймні в частині надання висновків на законопроекти про винесення змін до Конституції України (останнього разу -

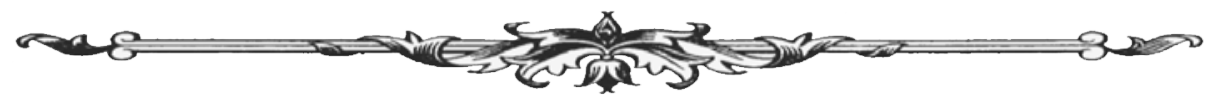


у висновку від 16 липня 2015 р. КСУ зробив висновок про неможливість бути предметом регулювання законопроекту про внесення змін до Конституції України окремих положень його розділу «Прикінцеві положення» через порушення принципу верховенства права).

Ключові слова: конституиійний контроль, висновок Конституціийного Суду України, попередній конституційний контроль, права людини, обмеження прав людини.

During the 22 years of its existence, the CCU has also delivered conclusions on 34 bills to amend the Constitution of Ukraine. The conclusions of the Constitutional Court of Ukraine often refer to the powers and status of public authorities and rather indirect restrictions on human rights. Moreover, the Court often uses the phrase "may lead to a restriction of rights", "indirectly may lead to a restriction of rights", rather than stating the fact that the proposed changes are revoked or restricted. The $\mathrm{CCU}$ assumes the possibility of a restriction that is legally equal to the restriction itself and concludes that there has been a violation of Article $157 \S 1$. Sometimes - in the presence of similar reasoning ("may lead to $<\ldots>$ restriction of citizens" constitutional rights") the changes are in accordance with Articles 157 and 158. It all depends on whether the judge inclines to judicial activism or self-restraint, not to mention the root causes of the different approach to the conclusions. However, the most striking example of judicial activism is the closure of proceedings in the case of "inconsistency" of changes, as well as their "blocking" due to contradiction with other articles of the Constitution of Ukraine. It should be noted that, since 2015, he has not given any negative (at least in part) opinion on the draft law on amendments to the Constitution of Ukraine, limited from time to time by what he calls "reservations". Starting from this period, the period of "restraint" in the activity of the Ukrainian Constitutional Court generally began, at least as regards the submission of the draft laws on amendments to the Constitution of Ukraine. Amendments to the Constitution of Ukraine of certain provisions of its section "Final Provisions" due to violation of the principle of the rule of law).

Key words: constitutional control, opinion of the Constitutional Court of Ukraine, preliminary constitutional control, human rights, restrictions on human rights.

Вступ. 3 погляду конституційного контролю за реалізацією установчої влади нині в Україні він існує в формі попереднього і наступного контролю за внесенням змін до Конституції України. Щодо наступного, то він стосується лише форми і вимог дотримання процедури внесення змін. Натомість попередній контроль $\epsilon$, зокрема, матеріальним, і передбачає надання відповідного висновку на відповідність змін ст. 157-158 Конституції України. Ст. 157 Конституції України забороняє вносити зміни, які обмежують або скасовують права людини. Саме на таких змінах і пропоную зосередити увагу в статті.

Постановка завдання. Метою статті є з'ясування терцій і закономірностей, які стосуються здійснення попереднього контролю за законопроектами щодо внесенням змін до Конституції України. Завдання статті: з'ясувати роль Конституційного Суду України (далі - КСУ) в механізмі внесення змін до Конституції України; розкрити сутність юридичних позицій КСУ при наданні висновків щодо внесення змін до Конституції України; з'ясувати особливості практики реалізації КСУ свого права щодо попереднього конституційного контролю при внесенні змін до Конституції України.

Результати дослідження. Практика скасування прав у змінах до Конституції України (або хоча б відповідна спроба) відсутня, натомість КСУ неодноразово звертав увагу у своїх висновках на обмеження прав людини. Загалом за 22 роки свого існування КСУ надав висновки на 34 законопроекти щодо внесення змін до Конституції України.

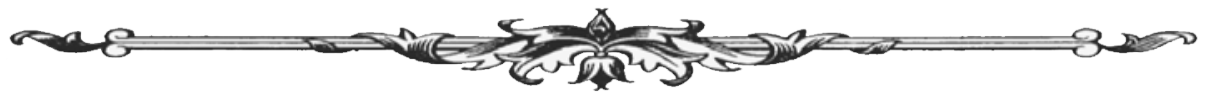


Першим негативним висновком КСУ став висновок від 25 березня 1999 р. 1-в [1], у якому КСУ визнав таким, що не відповідає вимогам ст. 157 Конституції України, положення законопроекту, згідно $з$ яким парламентський контроль, що його від імені Верховної Ради України здійснює Рахункова палата, визначається як «вищий». Покладення функцій «вищого парламентського контролю» на Рахункову палату - непредставницький орган, означало б звуження змісту й обсягу закріпленого у ст. 38 Конституції України права громадян брати участь в управлінні державними справами, обмеження здійснення цього права, чого Конституція України не допускає (ч. 1 ст. 157 Конституції України). Водночас КСУ звернув увагу на певні неузгодженості у законопроекті, зазначивши, що вирішення цих питань виходить за межі його повноважень у цій справі.

У Висновку КСУ (справа про внесення змін до ст. 46 Конституції України) [2] від 02 червня 1999 р. № 2-в/99 проект Закону України «Про внесення змін до ст. 46 Конституції України» визнано таким, що не відповідає вимогам ст. 157 Конституції України. У поданому на висновок КСУ проекті закріплене названою статтею право громадян на соціальний захист у старості пов'язувалося з досягненням ними певного віку.

У висновку від 27 червня 2000 р. № 1-в/2000 [3] КСУ визнав загалом законопроект таким, що відповідає ст. 157-158, проте рекомендував здійснити певні уточнення. Наявність такої рекомендації змінило підхід, який застосував КСУ до «суперечливих» змін у своєму першому висновку, зазначивши, зокрема:

- відсутність у Конституції України належної чіткості у визначенні змісту депутатської недоторканності на практиці може призвести до неоднозначного розуміння ч. 1 ст. 80 Конституції України. Зважаючи на це, до ст. 80 Конституції України доцільно внести відповідні уточнення;

- онституційний Суд України констатує, що запровадження в Конституції України поняття «постійно діюча парламентська більшість» логічно зумовлює потребу доповнити іiі гарантіями (хай навіть у загальній формі) для тієї частини складу Верховної Ради України, яка не входить до «постійно діючої парламентської більшості» та яку умовно можна характеризувати як «парламентську меншість». Невизначеність гарантій функціонування такої меншості може призвести до порушення однієї з основних засад, на яких грунтується суспільне життя в Україні - політичної та ідеологічної багатоманітності (ст. 15 Конституції України) й обмеження конституційних прав громадян, передбачених, зокрема, ст. 34 і 38 Конституції України;

- із внесенням зазначених змін до Конституції України логічно було б визначити принаймні у загальних рисах механізми, які забезпечували б бюджетний процес у разі дострокового припинення повноважень парламенту, адже його зупинення може призвести до невиконання вимог ч. 2 ст. 95 Конституції України, згідно з якою виключно законом про Державний бюджет України визначаються будь-які видатки держави на загальносуспільні потреби, розмір і цільове спрямування цих видатків, а отже, негативно вплинути на реалізацію соціальних, економічних та інших програм.

Суддя КСУ В.М. Шаповал у своїй окремій думці зауважив, що положення мотивувальної частини Висновку засвідчують, що КСУ розглядав справу і прийняв рішення в режимі de lege ferenda, тобто з позицій закону, прийняття якого є бажаним. Однак і за Конституцією України, і за чинним законодавством єдиний орган конституційної юрисдикції уповноважений діяти виключно в режимі de lege lata, тобто з позицій закону, який діє. КСУ уповноважений встановлювати, чи передбачають відповідні зміни до Конституції України скасування чи обмеження прав і свобод людини і громадянина (ч. 1 ст. 157 Конституції України), а не робити припущення, що ці зміни «можуть призвести до обмеження конституційних прав громадян».

У висновку від 11 липня 2000 р. № 2-в/2000 [4] (справа про внесення змін до Конституції України за ініціативою народних депутатів України) звернув увагу на «відсутність комплексних, системних змін до Конституції України у зв'язку із запровадженням двопалатного парламенту» в законопроекті та припинив провадження щодо низки положень законо-

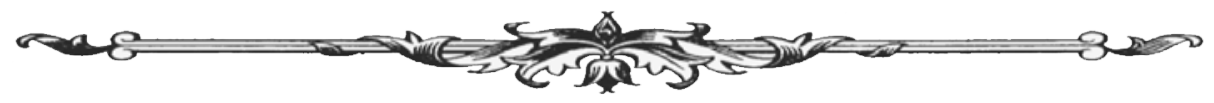


проекту. Передусім ішлося про впровадження інституту двопалатного парламенту. Таким чином, КСУ кардинально змінює свій попередній підхід до неузгодженостей у законопроекті. КСУ проявив значний активізм, що виявилося у відмові надавати висновок у певній частині змін у принципі, хоча раніше він вважав, що аналіз таких неузгодженостей не належить до його повноважень.

Одне положення законопроекту було визнане таким, що передбачає обмеження прав і свобод людини, а саме щодо надання згоди на притягнення до кримінальної відповідальності народних депутатів України Верховним Судом України. Зв'язок із обмеженням прав і свобод зазначеної пропозиції можемо побачити лише через посилання КСУ на ст. 6 СКПЛ 1950 р., детальної аргументації відповідного обмеження КСУ не наводить.

У висновку КСУ від 14 березня 2001 р. № 1-в/2001 були визнані такими, що не відповідають вимогам ч. 1 ст. 157 Конституції України, запропоновані зміни до п. 3 ч. 1 ст. 85 і ст. 150 Конституції України, за якими Верховній Раді України пропонувалося надати повноваження офіційно тлумачити закони України, а Конституційний Суд України позбавити цього повноваження [5].

Окрім згаданого зауваження, висновок КСУ від 14 березня 2001 р. № 1-в/2001 містив й інші положення, які були визнані такими, що не відповідають ст. 157-158. Зокрема, йшлося про:

- вилучення положення щодо здійснення народним депутатом України голосування на засіданнях Верховної Ради України особисто і заміну положенням про те, що порядок голосування на пленарних засіданнях Верховної Ради України встановлюється законом про регламент Верховної Ради України. На думку КСУ, отримавши депутатський мандат від виборців, народний депутат України через особисте голосування підтримує з ними зв'язок як їх представник, а з огляду на це виборці - громадяни України - реалізують своє право брати участь в управлінні державними справами (ч. 1 ст. 38) і здійснюють народне волевиявлення (ст. 69 Конституції України). Реалізація цих прав громадян гарантується Конституцією України. Пропоновані ж зміни, за якими право й обов'язок народного депутата України голосувати на засіданнях парламенту особисто вилучається зі ст. 84, передбачають скасування цих конституційних гарантій і їх можливе закріплення на рівні закону, а саме закону про регламент Верховної Ради України. При вирішенні цього питання Конституційний Суд України виходить із того, що зазначені зміни до Конституції України призведуть до обмеження окремих прав і свобод людини і громадянина та зниження рівня їх гарантій;

- наділення комітетів Верховної Ради України правом здійснювати парламентський контроль у межах та в порядку, встановлених законами України. Такі зміни до Конституції України призведуть також до зниження рівня гарантованості окремих конституційних прав і свобод людини і громадянина, звуження їх змісту й обсягу, отже, i до їх обмеження.

У згаданому висновку КСУ продовжив свою практику припинення провадження щодо тих чи інших положень законопроекту про внесення змін до Конституції України. Однією 3 підстав для цього стала неузгодженість між текстом законопроекту, який направлений для надання висновку, а також текстом, під яким поставили підписи народні депутати, що були ініціаторами законопроекту (йшлося про відсутність змін до ст. 93 Конституціі). Підставою для припинення провадження стала суперечливість між пропонованими змінами, їх неузгодженість 3 іншими положеннями Конституції, відсутність системного підходу. Йшлося про питання публікації і підписання законів, переліку актів, що підлягають контролю з боку КСУ, а також надання висновку КСУ на законопроект про внесення змін до Конституції України. Також КСУ припинив провадження щодо змін до розділу XV «Перехідні положення» Конституції України, оскільки ця норма Конституції України діяла тимчасово і зі створенням Конституційного Суду України вичерпала свою дію.

У висновку від 16 жовтня 2002 р. № 1-в/2002 [6] КСУ пішов новим шляхом - у випадку, коли він вже раніше давав висновок щодо схожих змін, які визнав такими, що не відповідають ст. 157, 158 Конституції - припиняти провадження. Так, розглянувши повторно (хоча й цілком інакше сформульовану) пропозицію щодо контролю з боку комітетів ВРУ, КСУ

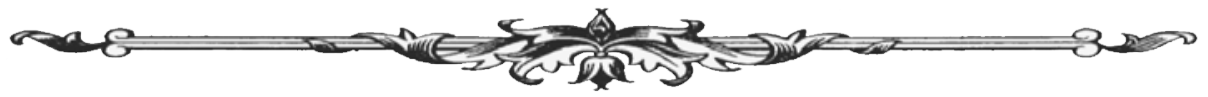


навів аргументи щодо суперечності іншим статтям Конституції України, передусім у частині правосуддя, послався на свій попередній висновок (від 14 березня 2001 р. № 1-в/2001), проте висновок про суперечність змін ст. 157 Конституції України не зробив і припинив провадження у справі. У цьомуразі КСУ не навів навіть аргументів щодо неузгодженості змін, а також не зробив висновку щодо обмежень прав людини. Виглядає так, що навести аргументи щодо обмеження прав людини КСУ або не зміг або вважав зайвим. Що ж стосується суперечливості самих змін як підстави у закритті провадження, то до цього висновку КСУ говорив виключно про системну суперечливість, що не дозволяє надати висновок. Суперечність окремим нормам Конституції сама по собі підставою для припинення провадження стає вперше. Це по суті революційне рішення КСУ, в якому він наділив сам себе повноваженнями здійснювати контроль не лише за відповідністю вимог ст. 157-158 Конституції України, а й іншим статтям, проте конкретні критерії перевірки і саме пояснення нової позиції не наводить.

КСУ у висновку від 30 жовтня 2003 р № 1-в/2003 [7] повторив свою позицію, висловлену у висновку від 14 березня 2001 р. № 1-в/2001 про те, що положення стосовно передання Верховній Раді України повноваження офіційного тлумачення законів України, а КСУ позбавити цього повноваження передбачають обмеження права індивіда звертатися до КСУ і тим самим право на судовий захист, встановленого ч. 1 ст. 55 Конституції України.

У цьому ж висновку КСУ висловив своє занепокоєння, що періодичне строкове переобрання суддів може призвести до зниження рівня гарантованою Конституцією незалежності суддів, проте скасування або обмеження прав людини у цьому не побачив. Як і у тому, що за змістом законопроекту існує невизначеність стосовно статусу суддів, що відповідно до чинної Конституції обрані безстроково (про це зазначає сам КСУ).

Аналогічне занепокоєння КСУ висловив також у висновку (справа про внесення змін до ст. 76, 78, 81 та інших Конституції України) від 05 листопада 2003 р. № 2-в/2003 [8]. У цьому ж висновку йшлося про необхідність узгодження словосполучення «представницький мандат народного депутата», що на думку КСУ тавтологічним. Також КСУ звернув увагу на необхідність законодавчої конкретизації повноваження ВРУ щодо нагляду прокуратурою за дотримання прав і свобод людини і громадянина, а також неузгодженість функції нагляду за дотриманням законів фактично всіма державними органами влади із принципом поділу влади. Також такою, що не узгоджується із структурою, визнана назва нового розділу XVI «Прикінцеві положення, які стосуються змін до Конституції України». Проте вперше КСУ по суті дозволив доповнювати Конституцію новими розділами і змінювати іï структуру.

КСУ не знайшов скасування або обмеження прав людини у положенні законопроекту щодо обрання Президента України, яке покладалося на Верховну Раду України. 3 цього приводу свої зауваження до висновку висловив суддя В. Скомороха. Інше зауваження було у судді В. Іващенко, який (як і раніше його колега В.М. Шаповал) зазначив, що інших критеріїв (умов) перевірки (визначених у ст. 157-158 Конституції України) КСУ законопроектів про внесення змін до Конституції України Основний Закон України не містить.

Питання $є$ й до висновку КСУ від 10 грудня 2003 р. № 3-в/2003 [9], яким він так само визнав таким, що не передбачає скасування чи обмеження прав і свобод людини і громадянина та не спрямоване на ліквідацію незалежності чи на порушення територіальної цілісності України положення законопроекту про обрання Президента України Верховною Радою України. Проте як це узгоджується із наявним у Конституції України правом обрання Президента всенародно і чому це не $є$ обмеженням пасивного виборчого права висувати свою кандидатуру на посаду Президента України, а також активного виборчого права обирати Президента, КСУ не навів.

У висновку (п. 10 мотивувальної частини) від 16 березня 2004 р. № 1-в/2004 [10] КСУ констатує наявність у законопроекті певних неузгодженостей у самому його тексті і $з$ приписами чинної Конституції України. Але усунення таких неузгодженостей, оскільки вони не скасовують і не обмежують прав і свобод людини і громадянина, не спрямовані на ліквідацію незалежності чи на порушення територіальної цілісності України, виходить за межі

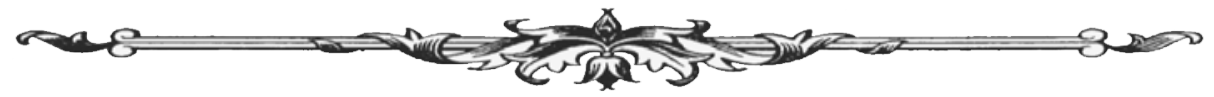


повноважень КСУ. А от, на думку судді М. Савенко, висловленій у його окремій думці до висновку, Суд не може залишити без уваги зміни, які призведуть до колізії норм Основного Закону України, викладені нечітко і їх потрібно буде обов'язково тлумачити, ставити під сумнів здатність органів державної влади здійснювати свої функції, повноваження тощо.

У висновку від 15 січня 2008 р. № 1-в/2008 [11] КСУ визнав таким, що не відповідає вимогам ч. 1 ст. 157 Конституції України в частині скасування інституту висловлення недовіри голові обласної державної адміністрації депутатами обласної ради, в т. ч. і можливість настання відповідних наслідків (ч. 9, 10 ст. 118 чинної Конституції України). КСУ дійшов висновку, що скасування інституту висловлення недовіри голові обласної державної адміністрації депутатами обласної ради може призвести до обмеження прав громадян, що суперечить вимогам ст. 157 Конституції України. Також, на думку КСУ, абз. 3 п. 8 розділу XV «Перехідні положення» вичерпав свою дію і не може бути предметом розгляду КСУ.

У цьому висновку КСУ також дав оцінку розділу законопроекту щодо внесення змін під назвою «Прикінцеві та перехідні положення», які, на думку КСУ, спрямовані на реалізацію змін до Конституції України. Пропоновані «Прикінцеві та перехідні положення» не передбачають скасування чи обмеження прав і свобод людини і громадянина. Тобто КСУ надав висновок не лише щодо змін до Конституції України за критеріями ст. 157-158, а й щодо усього законопроекту, хоч його положення текстом конституції не стають і змінам конституції формально не є. На думку ж судді Д. Лилака, КСУ не мав би взагалі розглядати цей законопроект на відповідність ст. 157-158 Конституції України через його «не перспективність», оскільки у зазначені терміни майбутній закон не міг набрати чинності i, відповідно, запропоновані в ньому могли бути внесені до Конституції України.

КСУ встановив обмеження прав громадян у висновку від 01 квітня 2010 р. № 1-в/2010 (щодо скасування недоторканності Президента, скасування можливості притягнення до відповідальності народних депутатів у частині наклепу або образи) [12]. На думку КСУ, пропоновані зміни про виключення зі ст. 105 Конституції України частини першої, доповнення її новою частиною та доповнення новим пунктом ст. 108 Конституції України можуть призвести до обмеження прав і свобод людини і громадянина, ліквідації незалежності та до порушення територіальної цілісності України, що не відповідає вимогам ч. 1 ст. 157 Конституції України. В чому саме таке обмеження, може проявитися незрозуміло. 3 одного боку, КСУ наголошує на неузгодженості, відсутності системного підходу при вирішенні питання щодо взаємозв'язку цих змін з іншими положеннями чинної Конституції України. 3 іншого боку, можна також припустити, що ключову роль зіграло визначення Президента гарантом державного суверенітету, територіальної цілісності України, додержання Конституції України, прав і свобод людини і громадянина. До речі формулювання «зміни можуть призвести до обмеження прав і свобод людини і громадянина» КСУ використовує не вперше.

Законопроектом також пропонувалося зі ст. 105 Конституції України виключити ч. 2, згідно з якою «за посягання на честь і гідність Президента України винні особи притягаються до відповідальності на підставі закону». Скасування відповідного положення КСУ також розцінив як такі, що суперечать ч. 1 ст. 157 Конституції України. Цікавою $є$ аргументація КСУ. Згідно з Основним Законом України Президент України є гарантом державного суверенітету, територіальної цілісності України, додержання Конституції України, прав і свобод людини та громадянина (ч. 2 ст. 102). Зазначені положення зобов'язують главу держави захищати усіма можливими правовими засобами, зокрема права і свободи людини і громадянина. Тому образа чи наклеп на Президента України можуть розглядатися не тільки як посягання на громадянські права особи, що перебуває на цьому посту, але й як прояв неповаги до Української держави та ії народу загалом.

У висновку від 17 червня 2010 р. № 2-в/2010 [13] КСУ визнав окремі запропоновані зміни такими, що обмежують права людини. КСУ вважає, що регулювання законодавцем правовідносин, пов'язаних із датою проведення голосування на виборах органів і посадових осіб місцевого самоврядування, а також із припиненням їх повноважень, має здійснюватися відповідно до п. 30 ч. 1 ст. 85, ст. 91, п. 20 ч. 1 ст. 92 Конституції України тільки після вне-

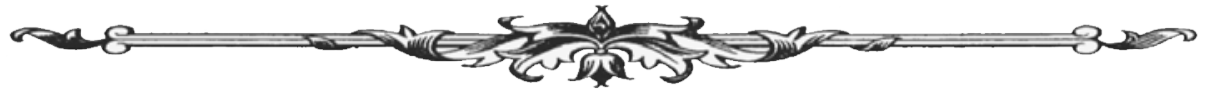


сення запропонованих до неї змін шляхом прийняття окремого правового акта, а не законопроекту, передбаченого розділом XIII «Внесення змін до Конституції України» Основного Закону України.

У висновку від 10 липня 2012 р № 1-в/2012 (щодо скасування недоторканності суддів) [14] КСУ підтвердив свою попередню позицію стосовно недоторканності Президента, аналізуючи аналогічні зміни і не пояснюючи нічого нового, просто пославшись на свій попередній висновок із цього питання (висновок від 01 квітня 2010 р № 1-в/2010). КСУ також дійшов висновку про те, що скасування такої гарантії правосуддя, як недоторканність суддів «опосередковано може призвести до обмеження права на судовий захист, гарантованого ст. 55 Конституції України». Теза щодо опосередкованості обмежень права є новою і не застосовувалася до цього КСУ.

У висновку від 16 червня 2015 р. № 1-в/2015 [15] КСУ відповідно до вже певної традиції висловлює занепокоєння щодо окремих норм, що стосуються недоторканності та притягнення до відповідальності суддів. Повторює КСУ і свою позицію щодо можливості наявності в законопроекті розділу «Прикінцеві положення», який КСУ також перевіряє на відповідність ст. 157-158 Конституції України. Проте КСУ вдруге пішов на прояв активізму у своєму висновку, прямо «заблокувавши» зміни в законопроекті з мотивів, які не стосувалися критеріїв, визначених у ст. 157-158 Конституції України. Так, КСУ зазначає, що положення п. 2, 3 розділу «Прикінцеві положення» не можуть бути предметом регулювання закону про внесення змін до Конституції України, оскільки вони не узгоджуються з вимогами ст. 8 Конституції України (принципом верховенства права).

Висновки. Підводячи підсумки, зазначу, що у висновках КСУ часто йшлося про повноваження і статус органів державної влади й опосередковані обмеження прав людини. Причому КСУ часто використовує конструкцію «можуть призвести до обмеження прав», «опосередковано може призвести до обмеження права», а не констатує факт скасування або обмеження прав пропонованими змінами. КСУ робить припущення про можливість обмеження, що юридично дорівнює самому обмеженню і робить висновок про порушення ч. 1 ст. 157. Іноді (за наявності схожої аргументації («може призвести до <..> обмеження конституційних прав громадян»)) КСУ просто констатує це як своє занепокоєння (іноді прямо називаючи це «застереженням») у мотивувальній частині рішення і робить протилежний висновок - зміни відповідають ст. 157 і 158. Все залежить від того, чи схиляються судді до судового активізму, чи до самообмеження, не кажучи про глибинні причини різного підходу до висновків. Проте найяскравіший приклад суддівського активізму - закриття провадження у разі «неузгодженості» змін, а також їх «блокування» через суперечність іншим статтям Конституції України. Зауважимо, що починаючи з 2015 р. взагалі не надав жодного негативного (хоча б частково) висновку на законопроект про внесення змін до Конституції України, обмежуючись час від часу тим, що він сам називає «застереженнями». Відтоді загалом почався період «стриманості» в діяльності українського КСУ, принаймні в частині надання висновків на законопроекти про винесення змін до Конституції України (останнього разу - у висновку від 16 липня 2015 р. КСУ зробив висновок про неможливість бути предметом регулювання законопроекту про внесення змін до Конституції України окремих положень його розділу «Прикінцеві положення» через порушення принципу верховенства права).

\section{Список використаних джерел:}

1. Висновок Конституційного Суду України від 25 березня 1999 р. № 1-в/99. URL: https://zakon.rada.gov.ua/laws/show/v001v710-99.

2. Висновок Конституційного Суду України від 02 червня 1999 р. № 2-в/99. URL: https://zakon.rada.gov.ua/laws/show/v002v710-99.

3. Висновок Конституційного Суду України від 27 червня 2000 р. № 1-в/2000. URL: https://zakon.rada.gov.ua/laws/show/v001v710-00.

4. Висновок Конституційного Суду України від 11 липня 2000 р. № 2-в/2000. URL: https://zakon.rada.gov.ua/laws/show/v002v710-00.

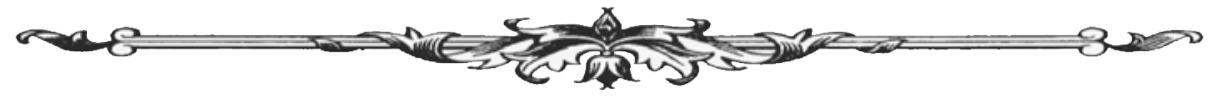


5. Висновок Конституційного Суду України від 14 березня 2001 р. № 1-в/2001. URL: https://zakon.rada.gov.ua/laws/show/v001v710-01.

6. Висновок Конституційного Суду України від 16 жовтня 2002 р. № 1-в/2002. URL: https://zakon.rada.gov.ua/laws/show/v001v710-02.

7. Висновок Конституційного Суду України від 30 жовтня 2003 р. № 1-в/2003. URL: http://zakon.rada.gov.ua/laws/show/v001v710-03.

8. Висновок Конституційного Суду України від 05 листопада 2003 р. № 2-в/2003. URL: https://zakon.rada.gov.ua/laws/show/v002v710-03.

9. Висновок Конституційного Суду України від 10 грудня 2003 р. № 3-в/2003. URL: http://zakon.rada.gov.ua/laws/show/v003v710-03.

10. Висновок Конституційного Суду України від 16 березня 2004 р. № 1-в/2004. URL: https://zakon.rada.gov.ua/laws/show/v001v710-04.

11. Висновок Конституційного Суду України від 15 січня 2008 р. № 1-в/2008. URL: https://zakon.rada.gov.ua/laws/show/ru/v001v710-08.

12.Висновок Конституційного Суду України від 01 квітня 2010 р. № 1-в/2010. URL: http://zakon.rada.gov.ua/laws/show/v001v710-10.

13.Висновок Конституційного Суду України від 17 червня 2010 р. № 2-в/2010. URL: https://zakon.rada.gov.ua/laws/show/v002v710-10

14.Висновок Конституційного Суду України від 10 липня 2012 р. № 1-в/2012. URL: http://zakon.rada.gov.ua/laws/show/v001v710-12.

15.Висновок Конституційного Суду України від 16 червня 2015 р. № 1-в/2015. URL: https://zakon.rada.gov.ua/laws/show/v001v710-15.

ГОцУЛЯк Ю. В., кандидат юридичних наук, доцент кафедри теорії та історії держави і права та адміністративного права (Донецький національний університет імені Василя Стуса)

DOI https://doi.org/10.32842/2078-3736-2019-6-1-3

\section{ІСТОРИКО-НАЦІОНАЛЬНІ ОСНОВИ ПРАВОВОГО БУТТЯ У ВЧЕННІ Ф. К. ФОН САВІНЬЇ}

Стаття присвячена розкриттю категорії правового буття у доктрині історичної школи права. У роботі обгрунтовується, що історична школа наголошує на обов'язковості часового виміру у праві. Право у часі не просто $\epsilon$, воно змінюється, а отже, час $є$ головним чинником його генезису. Автор доводить, що правове буття розкривається через розуміння, пізнання, засвоєння правових явищ, а не через його творення. Право це той параметр, що уже заданий буттям. Правова діяльність людини й істинний зміст права цілком можуть і не пересікатись, адже правова істина може суб'єктом і не розкритись або підмінити іiі зміст.

У статті аналізується позиція історичної школи, що правове буття розгортається не перспективно, а ретроспективно, воно уже розгорнуте, лиш потребує розумових вольових зусиль суб'єкта по збереженню його змісту. Для історичної школи права істині витоки всього правового можуть бути лише у націо-

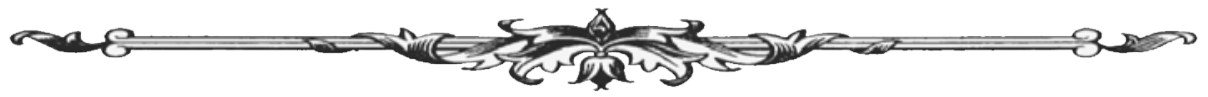

